\title{
ENTREVISTA COM ILANA HEINEBERG
}

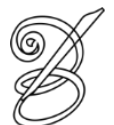 \\ Germana Henriques Pereira ${ }^{\mathrm{i}}$ \\ POSTRAD/UnB \\ germanahp@gmail.com \\ Patrícia Rodrigues Costai \\ (Doutoranda - PGET/UFSC) \\ prcosta1986@gmail.com
}

I

lana Heineberg é formada em jornalismo pela Pontifícia Universidade Católica do Rio Grande do Sul (PUC-Rio) e possui doutorado em Estudos Lusófonos Université de Paris III (Sorbonne-Nouvelle). Atualmente é professora da Université Michel de Montaigne-

Bordeaux 3, França, onde pesquisa principalmente os seguintes temas: romance-folhetim, romance brasileiro e romance francês do século XIX, literatura brasileira (séculos XIX e XX) e literatura comparada. É ainda tradutora do francês para o português.

Ilana,

Você se formou em jornalismo na PUC do RS, como você direcionou depois seus estudos para área de Letras? Qual foi seu grande motivador para essa virada?

Na metade do curso de Jornalismo, fiz vestibular para Letras na Universidade Federal do Rio Grande do Sul (UFRGS) e cursei os dois concomitantemente durante algum tempo. No final do curso de jornalismo, comecei a trabalhar no jornal Zero Hora (Porto Alegre) e diminuí as cadeiras no curso de Letras, mas senti que não estava totalmente no meu lugar no jornalismo. Acho que o que motivou a virada foi o cotidiano. Por um lado, eu gostava muito do ambiente da redação, da correria do fechamento, mas, por outro, sentia que precisava passar mais tempo trabalhando com um mesmo assunto e inclusive lendo e escrevendo um texto. Constatei que o ritmo do jornalismo diário não era o meu. No curso de Letras, fiquei entusiasmada com disciplinas de teoria e análise literária e tinha vontade de poder me dedicar inteiramente a isso. 
Então resolvi largar o jornalismo e ir para a França estudar um assunto que se situava no interstício dos campos literários e jornalísticos: o romance-folhetim.

Como se deu sua formação em literatura brasileira na França, mais precisamente em Paris III?

Foi uma experiência fundamental. Eu tinha 23 anos e estava numa capital literária mundial, com o único objetivo de ler, estudar, escrever, pesquisar e frequentar, seminários, livrarias e museus! No primeiro ano, fiz o Diplôme d'Études Approfondies (DEA, que atualmente foi substituído pelo Master). Eu tinha total liberdade para escolher os meus seminários. Além dos cursos da minha orientadora, Jacqueline Penjon, segui os de professores da literatura comparada (Jean Bessière, Daniel Henri-Pageaux...), da literatura francesa (Marc Dambre, Philippe Hamon, Mireille Sacotte...). Além disso, do ponto de vista pessoal, aprendi muito com a solidão e compensei essa condição com livros. A maioria das coisas que sei sobre a própria literatura brasileira, aprendi aqui na França. E não vejo isso de forma negativa. Acho 170 que algumas das questões fundamentais que surgiram em relação ao meu país e à sua produção cultural talvez nunca tivessem surgido se eu não tivesse saído do Brasil. Adquiri um distanciamento em relação à literatura brasileira que me fez ver as coisas de outra perspectiva, talvez mais ampla, mais geral, o que não é nem melhor nem pior, apenas diferente. O primeiro ano em Paris foi difícil, mas nem tanto, pois acabei ficando para cursar o doutorado.

Sua pesquisa de doutorado versou sobre romances de folhetim, qual a contribuição de sua pesquisa para os estudos no Brasil e na França desse gênero literário?

Na minha tese, busquei mostrar como o romance-folhetim contribuiu para a formação da literatura brasileira, facilitando a publicação e a circulação dos textos, mas principalmente como essa formação se reflete nos próprios textos folhetinescos: na figura do narrador, na representação do leitorado e das cenas de leitura, nos mecanismos humorísticos e na intertextualidade com obras brasileiras. Eu me interessei por textos seriados com no mínimo três episódios publicados entre 1839 e 1870 em grandes jornais do Rio de Janeiro (Jornal do commercio, Diário do Rio de Janeiro e Correio mercantil). Num volume anexo, listei todos os folhetins, brasileiros e estrangeiros publicados nesses periódicos e transcrevi folhetins de difícil acesso. Acho que o meu trabalho permite entender o folhetim numa perspectiva diacrônica, e 
não como algo estático. Acho também que dou pistas para compreender melhor a leitura no Brasil do século XIX já que o público que tinha acesso aos romances-folhetins (pela leitura individual ou pela leitura coletiva feita em voz alta) era bastante heteróclito. Procurei dispensar ao romance-folhetim o mesmo tratamento que se dá a outros textos literários, ou seja, busquei realmente analisá-los e não me limitei à sua história, aos paratextos ou às anedotas. Acredito que possa haver também interesse por esse trabalho na França, afinal, a matriz desse suporte de publicação é francesa - daí também a grande quantidade de folhetins traduzida do francês nos jornais que estudei. Havia, no Brasil, um diálogo importante com a produção literária francesa e com outros países, o que mostra a dimensão transnacional da cultura já no século XIX. No entanto, editores, autores, tradutores e leitores brasileiros apropriaram-se desse modelo francês, transformando-o em algo novo.

Vê-se que há uma confluência entre suas pesquisas sobre romance de folhetim e suas traduções de romances franceses. Como você se tornou tradutora de textos literários? Que gênero literário você traduz e de que línguas?

Há confluência, pois tive a sorte de poder traduzir textos literários que me interessavam, tanto enquanto leitora, como enquanto pesquisadora acadêmica. Eu me tornei tradutora traduzindo, depois de terminar a minha tese. A editora da L\&PM, que eu conhecia, precisava de tradutores para a empreitada da tradução da Comédia humana, de Balzac, e depois de alguns testes comecei com A menina dos olhos de ouro e depois vieram outros títulos e outros autores, como Georges Simenon. Também propus alguns títulos que eu gostaria de traduzir (sobretudo os romances da Nancy Huston). Ah, antes de tudo isso eu já havia tido uma experiência com a tradução do primeiro volume de $O$ Método, de Edgar Morin. Traduzi romances, contos, ensaios e biografias.

Você trabalha exclusivamente com a LP\&M? Como é o seu relacionamento com a editora?

Sim, mas foi um acaso por questões de contatos e relacionamento. Gostei muito de trabalhar com a L\&PM.

Em 2008, a L\&PM se viu envolvida em uma polêmica com a editora Nova Cultural. Traduções de algumas obras, resultantes de permuta entre a Nova Cultural e a L\&PM, foram 
consideradas plágio, dentre elas Madame Bovary e A Divina Comedia; o que resultou num processo da L\&PM contra a Nova Cultural. Além disso, as "obras traduzidas" foram recolhidas das livrarias e tradutores foram contratados para que estas obras fossem republicadas. Você foi a responsável pela nova tradução de Madame Bovary. Após essa polêmica, houve alguma ressalva da editora em relação à consulta de traduções anteriores? Há casos de plágio de traduções na França, assim como vem sendo comprovado no Brasil, que causem tamanha polêmica?

Eu só fiquei sabendo da polêmica mais tarde, não lembro que tenham me dado detalhes quando me convidaram para fazer a tradução. Também não recebi nenhuma ressalva da editora, até porque acredito que consultar outras traduções não tem nada a ver com plágio, se a tradução é feita de forma idônea. Se fosse assim todas as retraduções seriam suscetíveis de acusação de plágio, o que não é de forma alguma o caso! Prefiro consultar traduções em outras línguas, para ver as diferentes soluções encontradas, o que nem sempre ajuda a resolver um problema específico, mas permite pensar sobre a tradução, o que eu gosto muito de fazer. No caso da 172 Nancy Huston, que escreve diretamente em inglês e francês ou retraduz seus próprios romances, é muito interessante ver os tipos de soluções que ela mesma encontra quando transita entre esses idiomas. O tradutor que consulta outras traduções, precisa, antes, encontrar o seu tom e, depois, manter um estilo coerente ao longo do texto.

Não lembro de nenhuma polêmica sobre plágio em retraduções na França. Até porque os plágios envolvendo a editora Nova Cultural que você mencionou não foram crimes praticado por tradutores, mas pela editora, que copiou traduções anteriores atribuindo-as a tradutores totalmente fictícios.

Qual é o seu papel como tradutora na edição final do livro, por exemplo, com relação à escolha do título da tradução, paratextos como notas ou glossários, capas etc.?

Eu diria que, na edição final, o tradutor não participa muito. Nunca vi a capa de um romance que traduzi antes de receber um exemplar impresso. Ou seja, geralmente é uma surpresa ver a cara do bebê! Nos paratextos, podemos intervir um pouco mais. Um exemplo são as notas de rodapé que a L\&PM fez para os romances da Comédia humana. A instrução que recebemos foi de fazer uma nota de rodapé sumária quando um personagem da Comédia fazia a sua primeira aparição no romance que estávamos traduzindo. O mesmo foi feito para 
personagens históricos, o que permite ao leitor dessa edição de bolso, distinguir personagens fictícios e históricos e ter uma visão mais ampla da Comédia humana. Para isso utilizei o dicionário de personagens balzaquianos da Bibliothèque de la Pléaide e um livro intitulado Balzac et son monde, de Félicien Marceau. Nas minhas traduções, tive liberdade para fazer notas de tradução, mas sempre procurei usar esse recurso com moderação.

Em relação ao título, o caso mais interessante é o de Lignes de faille, de Nancy Huston. Traduzindo-se literalmente esse termo que vêm da geologia, temos Linhas de fratura, que são aquelas linhazinhas que se formam por movimentos ou deslocamentos de camadas mais profundas de um solo ou de uma rocha. Essas pequenas falhas podem se abrir expondo as camadas mais profundas. Acho que essa imagem ajuda muito a pensar o romance, afinal essa profundidade que se expõe, para mim, remete à infância dos quatro personagens, o que é reforçado pelo fato de a ordem cronológica aparecer de forma invertida no romance. Mas, em português, não usamos "linhas de fratura" metaforicamente o que torna o título pouco compreensível. As Marcas de nascença que atravessam as quatro gerações de personagens, também fazem parte da herança familiar. $\mathrm{O}$ título em português me pareceu conter algumas ideias importantes da intriga e instigar o leitor, pois guarda um certo mistério. Fiz algumas sugestões e os editores é que bateram o martelo.

Você é professora de tradução literária em Bordeaux: que formação básica deveria ter um tradutor de textos literários?

Particularmente, não acredito na obrigatoriedade de uma formação escolar específica, o percurso de um tradutor pode ser muito variado. Mas, mesmo que esse percurso seja o de um autodidata, de alguém que passou por grandes escolas de tradução, ou que tenha cursado, ao longo da sua formação, disciplinas de tradução literária, ele precisa escrever perfeitamente na língua alvo.

Você tem alguma metodologia particular para esse tipo de ensino, por exemplo com relação à escolha do corpus a ser traduzido em sala de aula?

As aulas que dou de tradução, sobretudo as de thème (tradução do francês para o português, ou seja, para os franceses, da língua materna para uma língua estrangeira) são consideradas como um exercício gramatical, uma forma de praticar a língua estrangeira. Mas, 
é claro que, como o assunto me interessa para além do exercício, acabo indo além e discutindo as possibilidades de tradução para uma eventual publicação. Quanto ao corpus, escolho trechos de acordo com o nível dos estudantes,e que estes devem traduzir em casa e depois corrigimos juntos. No início, trabalho mais com textos de imprensa ou com textos literários mais fáceis e, em função da progressão dos alunos, passo para obras mais difíceis e também recuo no tempo, indo até o século XIX. Na perspectiva da aula de thème, interesso-me por questões bastante variadas: tradução de tempos verbais, de expressões idiomáticas, das formas de tratamento, de gírias, de provérbio, do humor, da construção da frase etc. Incito os alunos a construírem fichas e glossários para que possam sistematizar certos procedimentos. Na França, o objetivo é que eles traduzam sem consultar dicionários, trabalhando o automatismo.

Como você procede na revisão das traduções feitas pelos estudantes?

Não posso considerar as traduções que faço com estudantes como traduções literárias que serão publicadas por uma editora. Aqui na França, são coisas bem diferentes. Os estudantes

174 são avaliados pela compreensão dos textos de partida e pelo bom uso da língua de chegada. É claro que, se algum aluno faz uma tradução excelente, sempre recompenso. A avaliação aqui é bem particular, baseada nos concursos para professor do ensino secundário, o Capes e a Agrégation. Há um sistema de dedução de pontos por tipos de erros. "Barbarismos" estão entre os mais graves ao passo que um erro ortográfico como a falta de um acento, vale menos.

Que tipo de formação deve ter um aprendiz de tradutor de textos literários?

Traduzir e escrever muito bem na língua para a qual se traduz. Ler muito nas línguas das quais traduz.

Você traduziu grandes clássicos para o português do Brasil, como Flaubert e Balzac, alguma dificuldade particular na tradução desses autores? Há alguma diferença importante na análise prévia do texto literário antes da tradução?

As dificuldades são diferentes em Balzac e Flaubert. Balzac tem uma escrita mais apressada, típica de alguém que escrevia sob o jugo do folhetim, ou seja, escrevia muito e rápido para pagar suas contas. O problema acaba sendo encontrar uma maneira de traduzir frases que 
às vezes são longas, sem serem perfeitamente construídas e algumas vezes até um pouco truncadas. Será que eu posso "melhorar" ou tornar mais clara uma frase de Balzac ao passar para o português? Já Flaubert era extremamente rigoroso e perfeccionista. Nenhuma palavra está ali por acaso. Cada vírgula, cada palavra tem um sentido preciso. Traduzindo Flaubert entendi que, por trás de uma frase límpida, aparentemente simples, há sempre um imenso trabalho de escrita e aperfeiçoamento.

Você traduziu Madame Bovary, quais estratégias você colocou em ação para traduzir os quadros descritivos, as cenas de multidão, as descrições de personagens? Você também poderia dizer, como Flaubert, "Bovary c'est moi?"

Antes de partir para a tradução propriamente dita de uma passagem mais complexa, eu lia e relia esses trechos, buscando visualizar a cena. Fazia uma pesquisa minuciosa para encontrar os equivalentes em português. Uma vez que tudo se tornava claro para mim, eu me sentia pronta para traduzir. Apesar desse mergulho na Normandia e no mundo de Madame Bovary, não posso dizer “Madame Bovary, c'est moi!". Ele teria dito essa frase para indicar que Madame Bovary saiu inteiramente da imaginação dele. Não é o meu caso, felizmente para os leitores da tradução!

Você consultou as traduções anteriores de Madame Bovary antes de fazer a sua, ou ainda durante o processo tradutório? O que você acha dessas retraduções em livro de bolso dos clássicos da literatura?

Consultei algumas, sim. Gosto de ver, antes de traduzir, como outros tradutores se apropriaram do texto. A gente sabe que as obras originais não envelhecem, mas as traduções sim. É por isso, em princípio, que se retraduz um texto. Para encontrar soluções para questões de tradução do francês, prefiro pesquisar por minha conta. Lembro que encontrei, por exemplo, dicionários e glossários de normandismos que me ajudaram muito, bem como artigos e análises extremamente precisos sobre Madame Bovary.

Acho bacana que os clássicos fiquem acessíveis a todos, mas claro que isso não deve ocorrer em detrimento da qualidade das traduções. Não conheço todas as traduções que foram feitas para edições de bolso, por isso não posso julgar esse aspecto. 
Você traduziu a biografia de Virgínia Woolf, fale-nos desse trabalho. Você dá a esse tipo de texto um tratamento diferente ao que você daria por exemplo à tradução de um romance?

Eu traduzi as biografias da Virginia Woolf e do Balzac. Faço esse tipo de trabalho com a mesma seriedade, mas logicamente um texto de registro mais referencial não apresenta as mesmas dificuldades de um texto literário do século XIX. A tradução avança mais rápido, então sei que posso fazê-la em um prazo menor.

Algum trabalho recente ou em processo atualmente?

As traduções mais recentes foram as do romance Lignes de faille (Marcas de nascença) e do ensaio Espèce fabulatrice (Espécie fabuladora), da escritora anglófona canadense, mas que tem escrito muitos livros em francês, Nancy Huston, que já mencionei antes. Não estou traduzindo nada atualmente, mas estou fazendo uma pesquisa sobre tradução, ou melhor, história da tradução. Estou estudando as traduções de Alencar, Machado e Taunay na França,

176 durante o século XIX. Essa pesquisa faz parte de um projeto temático sobre a Circulação transatlântica dos impressos: a globalização da cultura no século XIX, coordenado pela professora Márcia Abreu, da Unicamp. Nesse estudo me interesso sobretudo por traduções raras que foram publicadas em folhetins.

O que mais te apetece traduzir?

A mesma coisa que gosto de ler e estudar: romances!

RECEBIDO EM 20/12/2014 ACEITO EM 05/01/2015

\footnotetext{
' Lattes Germana Henriques Pereira. Disponível em: http://lattes.cnpq.br/5479032498605468. Acesso: jan. 2015.

${ }^{i i}$ Lattes Patrícia Rodrigues Costa. Disponível em: http://lattes.cnpq.br/9546437584230118. Acesso: jan. 2015.
} 